\title{
Penerapan Arsitektur Ekologi Dalam Perancangan Pusat Penelitian Agrikultur Di Kabupaten Sragen
}

\author{
Lailatul Amna $^{1^{*}}$, Tri Yuni Iswati ${ }^{2}$, Edi Pramono Singgih ${ }^{3}$ \\ Program Studi Arsitektur Universitas Sebelas Maret Surakarta ${ }^{1}$ \\ ela_amna@yahoo.com* \\ Program Studi Arsitektur Universitas Sebelas Maret Surakarta ${ }^{2}$ \\ Program Studi Arsitektur Universitas Sebelas Maret Surakarta ${ }^{3}$
}

\begin{abstract}
Indonesia is known as an agricultural country, which means Indonesia has high rate of agricultural production. However, Indonesia has not fully fulfilled its own food needs, seeing by the high number of food imports to Indonesia. Therefore, the government's agricultural development program is established which includes the development of science and technology (IPTEK) in agriculture. The application of Ecological Architecture theory is considered appropriate because it involves all related elements in the design of human, building and nature. This research is aimed to determine the design of research centre building which is able to facilitate the research activities in accordance with the standard of research space based on the principle of Ecological Architecture theory. The method used is data collection based on literature study, observation and comparation to the design object and application of Ecological Architecture theory, which is then applied as design strategies on the design object, starting from site selection, site analysis, as well as façade analysis. From the analysis that has been done then generated a research centre design that can support the sustainability of agricultural research activities based on the application of Ecological Architecture theory.
\end{abstract}

Keywords: research centre, agriculture, ecological architecture.

\section{PENDAHULUAN}

Indonesia terletak pada daerah iklim tropis yang menjadikan Indonesia memiliki keanekaragaman sumber daya alam. Tidak hanya sumber daya alamnya yang beraneka ragam, Indonesia pun memiliki lahan pertanian yang luas dengan luas lahan pertanian mencapai 8,2 juta hektar (BPS Pertanian 2013), serta hasil produksi pertanian yang berlimpah. Sumber daya manusianya pun melimpah, yaitu $36.5 \%$ dari jumlah penduduk yang bekerja merupakan petani, baik sebagai buruh tani maupun petani (BPS Pertanian 2013). Hal ini membuat Indonesia dikenal sebagai negara agraris yaitu negara yang memiliki potensi berupa sumber daya alam dan sumber daya manusia yang melimpah dalam bidang pertaniannya.

Melihat kondisi yang ada, pemerintah berencana untuk menjadikan Indonesia sebagai negara swasembada pangan. Namun kenyataan yang ada tidak sejalan, dilihat dari angka impor pangan Indonesia yang masih tinggi, yaitu sekitar 13,1\% per tahun (menurut Badan Pusat Statistik Pertanian Indonesia tahun 2014), yang secara tidak langsung dapat diartikan bahwa negara Indonesia belum mampu untuk memenuhi kebutuhan pangannya sendiri.

Untuk turut mengoptimalkan potensi pertanian Indonesia, pemerintah pun telah merencanakan Program Pembangunan Pertanian yang di dalamnya mencakup pengembangan ilmu pengetahuan dan teknologi (IPTEK) pada bidang pertanian. Pengembangan ilmu pengetahuan dan teknologi (IPTEK) sendiri mencakup adanya kegiatan penelitian dan pengembangan terhadap bidang pertanian yang dapat mendukung adanya inovasi dalam bidang pertanian (RENSTRA Kementan 2015 -2019).

Kabupaten Sragen merupakan wilayah yang mendapat prioritas dalam perkembangan sektor pertanian dibanding wilayah lainnya di 
Indonesia. Hal ini dilihat dari luasnya lahan peruntukan pertanian di Kabupaten Sragen dengan luas wilayah $40.339 \mathrm{Ha}$ sebagai luas wilayah sawah lahan basah, 24.795 Ha sebagai luas wilayah sawah lahan kering, serta 41.082,39 Ha untuk luas lahan pertanian pangan berkelanjutan menurut Rencana Tata Ruang Wilayah Jawa Tengah Tahun 20092029.

Oleh karena itu, berdasarkan data yang ada, dibutuhkan sebuah wadah yang dapat mendukung keberlangsungan program pembangunan pertanian terutama dalam bidang ilmu pengetahuan dan teknologi (IPTEK) yaitu kegiatan penelitian pertanian, khususnya di Kabupaten Sragen. Suatu desain yang mengaplikasikan pendekatan Arsitektur Ekologi sebagai pendekatan desain arsitektur berwawasan lingkungan, yang dapat menunjang keberlangsungan alam sekitar dan meminimalisir dampak negatif dari keberadaan bangunan yang direncanakan

\subsection{Arsitektur Ekologi}

Menurut Heinz Frick (1997), arsitektur ekologis merupakan suatu konsep desain arsitektur kemanusiaan yang memperhitungkan keselarasan antara manusia dengan lingkungannya.

Prinsip dasar teori Arsitektur Ekologi berfokus pada hubungan timbal balik yang menguntungkan antara elemen alam, bangunan dan manusia. Hal ini tentunya melibatkan adanya pengolahan lingkungan, pengolahan bangunan dan keterlibatan manusia dalam pembangunan yang harmonis.

Berdasarkan tinjauan teori pendekatan Arsitektur Ekologi menurut Heinz Frick, prinsip-prinsip ekologi yang dapat diterapkan pada bangunan yang direncanakan yaitu:

a. Desain yang Beradaptasi dengan Lingkungan

Keadaan eksisting tapak dan elemen-elemen yang ada di dalamnya dapat menjadi bahan pertimbangan dalam mendesain bangunan. Dengan menerapkan aplikasi ini, maka akan tercipta desain yang responsif dan senantiasa dapat beradaptasi dengan lingkungannya, mulai dari bentuk bangunan, fasad dan penempatan bangunan, orientasi bangunan, serta pengolahan site secara ekologis.

b. Pemanfaatan Sumber Daya Energi dan Sumber Daya Alam dengan Efisien

Dengan melakukan subsitusi sumber energi yang tidak dapat diperbarui yaitu dengan meminimalisir penggunaan alat pendingin, dan memajukan penggunaan energi alternatif seperti solar panel. Penggunaan bahan bangunan yang dapat dibudidayakan dan hemat energi yaitu dengan memilih bahan bangunan menurut penggunaan energi, menghemat sumber daya mentah yang tidak dapat diperbaharui, dan penggunaan kembali bahan bangunan sisa layak pakai.

Pemanfaatan sumber daya alam yang ada pun dapat diterapkan melalui penggunaan prinsip pada pemilihan material bangunan, pengolahan energi bangunan dan dukungan alam serta efisiensi dan konservasi energi pada lingkungan.

\section{c. Keseimbangan antara Sistem Bangunan dengan Lingkungan Alam Sekitar}

Untuk mewujudkan desain arsitektur yang ekologis, dibutuhkan adanya suatu sistem dalam bangunan yang ramah terhadap lingkungan selama siklus hidup bangunan. Hal ini dilakukan dengan pembentukan siklus atau peredaran yang utuh antara penyediaan dan pembuangan hasil metabolisme bangunan, mulai dari proses pembangunan, pemakaian serta perawatan bangunan.

\subsection{Pusat Penelitian Agrikultur}

Sebuah fasilitas penelitian merupakan sekelompok bangunan yang masuk dalam kategori sarana prasarana yang mewadahi kegiatan penelitian dan fasilitas-fasilitas yang menunjang kegiatan penelitian. Dalam sebuah bangunan penelitian, terjadi suatu proses interaksi antara subjek dan objek penelitian, yaitu proses action viewer, proses creative thinking, juga memungkinkan transfer of knowledge, science and technology, sehingga menuntut konsentrasi, kecermatan dan persyaratan tinggi.

Bangunan penelitian ialah suatu bangunan unit terpadu dan berkelanjutan yang meliputi fasilitas laboratorium, serta fasilitas penunjang 
lainnya. Macam penelitian yang diwadahi dalam bangunan di antaranya:

\section{a. Penelitian Fisiologis Hasil}

Penelitian fisiologis hasil diterapkan untuk meningkatkan nilai produk hasil pertanian, seperti dikembangkannya teknologi penggunaan zat pengatur tumbuh, dan juga untuk mendukung program pemuliaan tanaman.

\section{b. Penelitian Ekofisiologi}

Penelitian untuk mengeksplorasi proses fisiologis yang mempengaruhi pertumbuhan, reproduksi, kelangsungan hidup, adaptasi dan evolusi tanaman.

\section{c. Penelitian Pembenihan}

Penelitian mengenai cara-cara untuk dapat memperbaiki sifat-sifat genetik dan fisik dari benih. Penelitian Pembenihan sendiri ditujukan untuk menghasilkan benih-benih unggul yang dapat mendukung keberlangsungan pertanian.

\section{d. Penelitian Kultur Jaringan}

Kultur jaringan tanaman merupakan teknik menumbuh kembangkan bagian tanaman, baik berupa sel, jaringan atau organ dalam kondisi aseptic secara in vitro.

\section{e. Penelitian Hama dan Penyakit Tanaman}

Hal yang diteliti dalam penelitian hama dan penyakit tanaman yaitu, mengenai fitopatologi (jamur, bakteri, virus dan nematode), Sentomologi (serangga hama dan serangga bermanfaat), dan juga pengendalian hayati hama dan penyakit.

\section{METODE}

Bangunan yang direncanakan menerapkan teori desain Arsitektur Ekologi sebagai pendekatan desain arsitektur berwawasan lingkungan.

Metode perancangan sendiri dimulai dari pencarian ide, pengumpulan data, analisis permasalahan dan penentuan strategi desain. Pencarian dan pemantapan ide perancangan dilakukan melalui pencarian informasi dan data-data arsitektural maupun non-arsitektural. Kemudian selanjutnya, melakukan pengumpulan dan pengolahan data melalui studi observasi, studi literatur, serta studi komparasi terhadap objek rancang bangun serta penerapan teori Arsitektur Ekologi.

Setelah mendapatkan data yang dibutuhkan, dilakukan perencanaan terhadap aktivitas dan kebutuhan ruang berdasarkan kebutuhan objek pusat penelitian, yang dilanjutkan dengan menguraikan aplikasi prinsip-prinsip Arsitektur Ekologi. Kemudian data-data tersebut dianalisis menjadi strategi perancangan desain dalam menjawab persoalan desain dari objek rancang bangun berdasarkan prinsip Arsitektur Ekologi yang telah ditentukan sebelumnya, dengan hasil:

\section{- $\quad$ Persoalan Site}

Dibagi menjadi dua, yaitu penentuan lokasi serta pengolahan site. Penentuan lokasi sendiri dipilih berdasarkan penerapan prinsip teori ekologi yaitu pemanfaatan sumber daya alam dan energi, yaitu dengan memilih kawasan peruntukan pertanian, yang memiliki sumber daya alam dan energi yang dapat dimanfaatkan sesuai dengan kebutuhan bangunan.

Pengolahan site didasarkan atas pertimbangan sirkulasi bangunan, perletakan fungsi bangunan dalam site yang diaplikasikan menggunakan prinsip desain ekologi yaitu desain yang beradaptasi dengan lingkungan.

\section{- Persoalan Peruangan}

Membahas mengenai penentuan konsep bentuk ruang, kualitas ruang, pola tata ruang berdasarkan teori Arsitektur Ekologi yaitu desain yang beradaptasi dengan lingkungan dan keseimbangan sistem bangunan dengan alamsekitar, dengan menentukan konsep peruangan yang beradaptasi dengan lingkungan berdasarkan persyaratan ruang, kenyamanan dan keamanan pengguna, serta peletakkan ruang dalam dan pola sirkulasi yang berkesinambungan.

\section{- $\quad$ Persoalan Bentuk}

Persoalan bentuk yang mencakup penentuan bentuk dan pola tata massa menggunakan prinsip desain yang beradaptasi dengan lingkungan, yaitu dengan menentukan konsep bentuk dan pola tata massa yang sesuai fungsi, dinamis dan serta sesuai dengan fungsi dan aktivitas pengguna bangunan. 


\section{- Persoalan Tampilan}

Persoalan tampilan bangunan dengan merancang tampilan bangunan yang dapat mencerminkan pusat penelitian serta penerapan teori Arsitektur Ekologis. Strategi desain dengan menerapkan prinsip desain yang beradaptasi dengan lingkungan dan memanfaatkan sumber daya alam sekitar, yaitu dengan menggunakan bahan dan material berdasarkan pemilihan material ramah lingkungan, tekstur dan warna dan bukaan sebagai bentuk pemanfaatan sumber daya alam.

\section{HASIL PEMBAHASAN}

Hasil pembahasan merupakan penjelasan mengenai hal-hal yang telah dianalisis dan diproses sebelumnya terkait dengan persoalan perancangan bangunan yang dikaitkan dengan pendekatan Arsitektur Ekologi. Analisis meliputi aktivitas dan kebutuhan ruang, lokasi terpilih, pencapaian, iklim dan lingkungan, peruangan, gubahan massa, material dan bahan, serta utilitas bangunan.

\subsection{Aktivitas dan Kebutuhan Ruang}

Aktivitas yang akan diwadahi dalam objek rancang bangun dapat diketahui melalui analisis pengguna bangunan, yang dari kegiatan tersebut didapatkan kebutuhan ruang yang diperlukan untuk dapat menunjang kegiatan yang akan diwadahi. Secara garis besar, terdapat 5 kelompok kegiatan yang diwadahi dalam objek rancang bangun, sehingga didapatkan kebutuhan ruang yang diperlukan. (lihat Tabel 1)

Tabel 1. Kegiatan dan Kebutuhan Ruang

\begin{tabular}{lll}
\hline $\begin{array}{l}\text { Kelompok } \\
\text { Kegiatan }\end{array}$ & $\begin{array}{l}\text { Bentuk } \\
\text { Kegiatan }\end{array}$ & $\begin{array}{l}\text { Kebutuhan } \\
\text { Ruang }\end{array}$ \\
\hline $\begin{array}{l}\text { Penunjang: } \\
\text { Penerimaan }\end{array}$ & Masuk Area & Entrance Gate \\
& Parkir & $\begin{array}{l}\text { Parking } \\
\text { Lot }\end{array}$ \\
& Kendaraan & Penerimaan \\
& Mencari & \\
& Informasi & R. Staff \\
Penelitian & Beristirahat & Peneliti \\
& & R. Asisten \\
& & Staff \\
& & Lab. Fisiologis \\
& Meneliti & Hasil \\
& & Lab. \\
& & Ekofisiologis \\
\hline
\end{tabular}

\begin{tabular}{|c|c|c|}
\hline $\begin{array}{l}\text { Kelompok } \\
\text { Kegiatan }\end{array}$ & $\begin{array}{l}\text { Bentuk } \\
\text { Kegiatan }\end{array}$ & $\begin{array}{l}\text { Kebutuhan } \\
\text { Ruang }\end{array}$ \\
\hline & & $\begin{array}{l}\text { Lab. } \\
\text { Pembenihan } \\
\text { Lab. Kultur } \\
\text { Jaringan } \\
\text { Lab. Hama dan } \\
\text { Penyakit } \\
\text { Tanaman }\end{array}$ \\
\hline & $\begin{array}{l}\text { Praktik } \\
\text { Lapangan }\end{array}$ & $\begin{array}{l}\text { Kebun } \\
\text { Penelitian } \\
\text { Green House } \\
\text { Growth } \\
\text { Chamber }\end{array}$ \\
\hline & $\begin{array}{l}\text { Menguji } \\
\text { Fertilissasi }\end{array}$ & R. Fertilisasi \\
\hline & $\begin{array}{l}\text { Mendinginkan } \\
\text { Penelitian }\end{array}$ & R. Pendingin \\
\hline & $\begin{array}{l}\text { Menyemai } \\
\text { Benih }\end{array}$ & R. Penyemaian \\
\hline \multirow[t]{3}{*}{ Pelatihan } & $\begin{array}{l}\text { Pemberian } \\
\text { Materi }\end{array}$ & $\begin{array}{l}\text { Ruang } \\
\text { Workshop }\end{array}$ \\
\hline & $\begin{array}{l}\text { Pengetahuan } \\
\text { Visual }\end{array}$ & $\begin{array}{l}\text { Ruang } \\
\text { Multimedia }\end{array}$ \\
\hline & $\begin{array}{l}\text { Praktik } \\
\text { Percobaan }\end{array}$ & Ruang Praktik \\
\hline \multirow[t]{2}{*}{ Pengelola } & $\begin{array}{l}\text { Memimpin } \\
\text { Puslitbang }\end{array}$ & R. Pimpinan \\
\hline & Mengelola & $\begin{array}{l}\text { R. TU } \\
\text { R. Litbang } \\
\text { R.Kerjasama\&P } \\
\text { endayagunaan } \\
\text { R. Informasi \& } \\
\text { Promosi } \\
\text { R. Program \& } \\
\text { Evaluasi }\end{array}$ \\
\hline \multirow[t]{5}{*}{ Penunjang } & $\begin{array}{l}\text { Membaca } \\
\text { Mencari } \\
\text { Referensi }\end{array}$ & Perpustakaan \\
\hline & Berkumpul & Auditorium \\
\hline & Beribadah & Mushola \\
\hline & Menginap & Guest House \\
\hline & Makan & Kantin \\
\hline
\end{tabular}

\subsection{Lokasi Terpilih}

Pemilihan lokasi didasarkan pada pertimbangan kemudahan sirkulasi dan pencapaian dari dan menuju site, potensi lingkungan site yang dapat menunjang fungsi bangunan, serta sesuai dengan rencana pola pemanfaatan ruang RTDK dan RTRW Kabupaten Sragen tahun 2011 - 2031. Berdasarkan RTRW Kabupaten Sragen, kemudian dipilih Kecamatan Masaran dengan pertimbangan bahwa Kecamatan Masaran merupakan salah satu wilayah yang memiliki potensi pertanian yang dapat menunjang keberlangsungan objek rancang bangun. 
Selanjutnya, berdasarkan analisis prinsip teori dari strategi desain, maka dipilihlah dua lokasi (lihat Gambar $1 \&$ 2). Yang di mana dari hasil penilaian tersebut dipilihlah lokasi 2 (lihat Gambar 2) sebagai lokasi tapak bangunan pusat penelitian yang direncanakan.
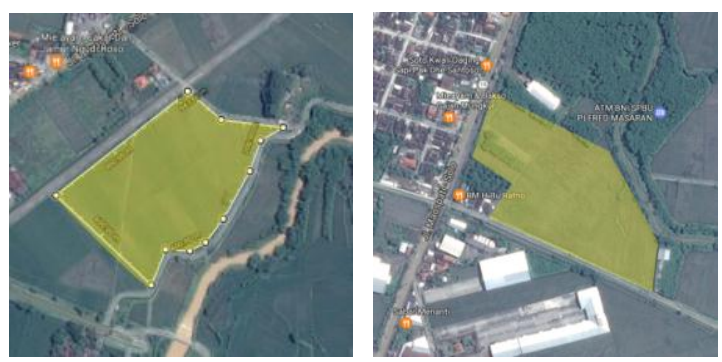

Gambar 1. Alternatif 1 (Kiri) (Google Earth, 2017)

Gambar 2. Alternatif 2 (Kanan) (Google Earth, 2017)

\subsection{Pencapaian, Iklim dan Lingkungan}

Pencapaian menuju bangunan haruslah memudahkan pengguna bangunan, oleh sebab itu main entrance site diletakkan berbatasan langsung dengan jalan utama yang penempatannya tidak menimbulkan kemacetan serta pengadaan side entrance site yang berbatasan dengan jalan lingkungan. (lihat Gambar 3)

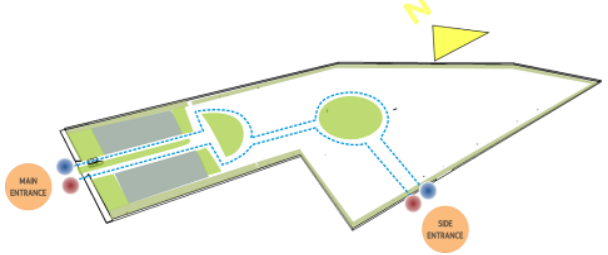

Gambar 3. Analisis Pencapaian

Analisis iklim dan lingkungan meliputi analisis mengenai matahari, angin dan kebisingan lingkungan berdasarkan kebutuhan bangunan dan teori Arsitektur Ekologi.

Analisis matahari menghasilkan suatu konsep bagaimana mengolah penataan vegetasi serta pola tata massa bangunan dalam site serta menentukan bagian bangunan yang memerlukan bukaan serta barrier sesuai dengan kebutuhan dan kondisi matahari pada site. (lihat Gambar 4)

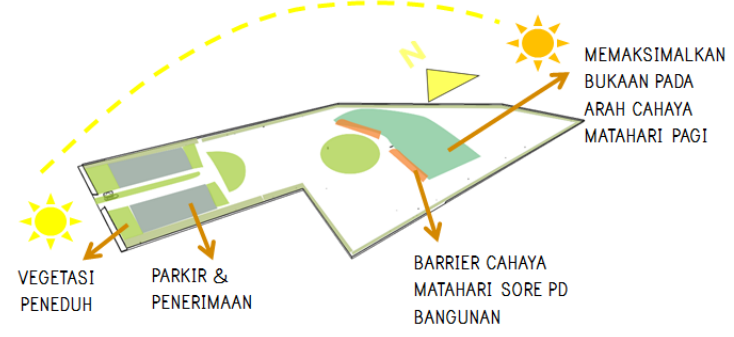

Gambar 4. Analisis Matahari

Analisis pergerakan arah angin ditujukan untuk mengetahui pergerakan arah angin ke dan dalam site, sehingga menghasilkan suatu konsep mengenai bagaimana menata perletakkan ruang dan bangunan yang memerlukan penghawaan alami dan massa bangunan dalam site agar tercipta jalur sirkulasi yang baik dalam site. (lihat Gambar $5)$.

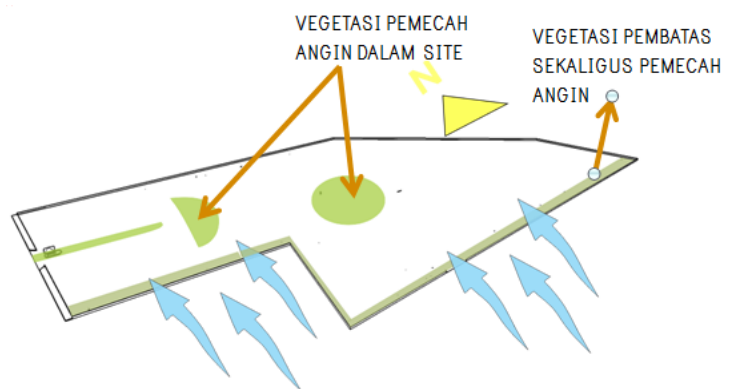

Gambar 5. Analisis Arah Angin

Analisis kebisingan ditujukan untuk mendapatkan konsep mengenai penataan zoning kelompok kegiatan berdasarkan persyaratan ruang akan kebisingan. Konsep kebisingan yang muncul yaitu dengan meletakkan zona kegiatan yang membutuhkan tingkat ketenangan pada area dengan tingkat kebisingan rendah, dan lainnya. (lihat Gambar 6)

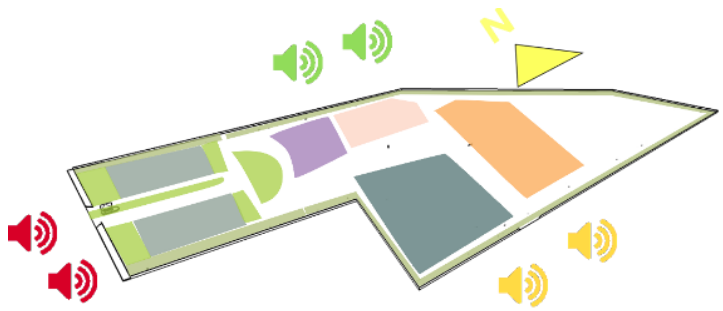

Gambar 6. Analisis Sumber Kebisingan

\subsection{Peruangan}

Konsep peruangan ditentukan berdasarkan kebutuhan ruang, karakter kegiatan dan aplikasi teori arsitektur ekologis. Kebutuhan 
ruang dianalisis berdasarkan kelompok pengguna serta kelompok kegiatan yang akan diwadahi di dalamnya (lihat di Tabel 1). Setelah ditentukan ruang-ruang yang akan diwadahi, dibentuklah suatu pola organisasi hubungan ruang yang menjelaskan mengenai kedekatan antar ruang berdasarkan kebutuhan dan sifat ruangnya (lihat Gambar 7 \& Gambar 8), yang kemudian ruang-ruang tersebut diwujudkan dalam bentuk desain perancangan berdasarkan sifat dan persyaratan ruangnya. (lihat Tabel 2)

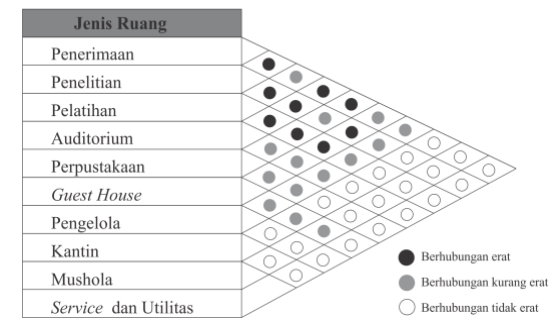

Gambar 7. Pola Hubungan Ruang Makro

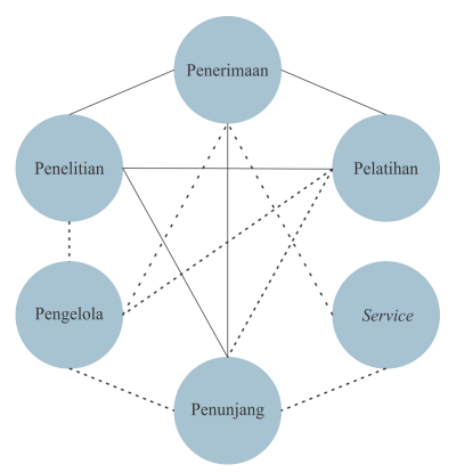

Gambar 8. Organisasi Ruang Makro

Tabel 2. Analisis Bentuk Dasar Ruang

\begin{tabular}{|l|l|}
\hline Bentuk Ruang & \multicolumn{1}{|c|}{ Karateristik } \\
\hline Persegi & $\begin{array}{l}\text { - efisien dan } \\
\text { fleksibel dalam } \\
\text { segi fungsi } \\
\text { - cenderung kaku } \\
\text { dan tidak dinamis } \\
\text { namun dapat } \\
\text { menyesuaikan } \\
\text { dengan bentuk } \\
\text { lain. }\end{array}$ \\
\hline
\end{tabular}

\section{Kualitas Ruang}

\section{a. Interior: Ruang Laboratorium}

Ruang laboratorium memiliki bentuk dasar persegi, karena dibutuhkan ruangan dengan bentuk simetris dan sederhana. Layout laboratorium ditata sesuai dengan dimensi peralatan serta flow dalam ruangan sehingga tercipta kenyamanan.

Membangun sistem yang seimbang dalam bangunan sehingga kegiatan dapat diwadahi dengan baik merupakan prinsip Arsitektur Ekologi yang diterapkan pada perancangan ruang, yaitu dengan mengadakan bantuan pencahayaan buatan karena ruang labortorium membutuhkan pencahayaan konsisten sebesar 500 lux, dan merancang tinggi langit-langit standar yang tidak terlalu tinggi sehingga ruang di bawahnya mendapat pencahayaan buatan yang cukup, serta menggunakan warna netral yang dapat meningkatkan tingkat fokus dan konsentrasi. (lihat Gambar 9)

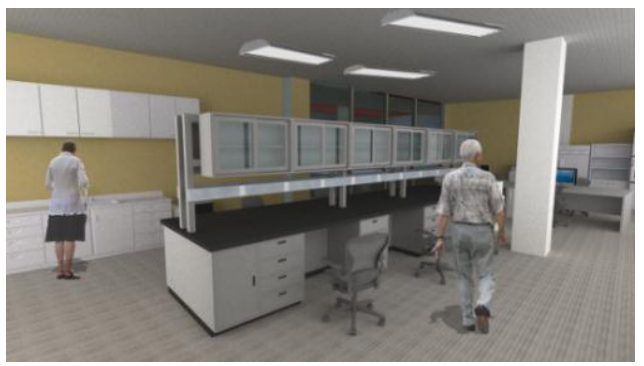

Gambar 9. Interior Ruang Laboratorium

Pada eksterior bangunan yang menghadap arah barat, diterapkan penggunaan sun shading sebagai penghalau sinar matahari sore yang kurang bermanfaat, dan juga teritisan sebagai pemberi shading pada bangunan agar mengurangi panas dalam bangunan sebagai bentuk penerapan strategi desain yang beradaptasi dengan lingkungan. (lihat Gambar 10)

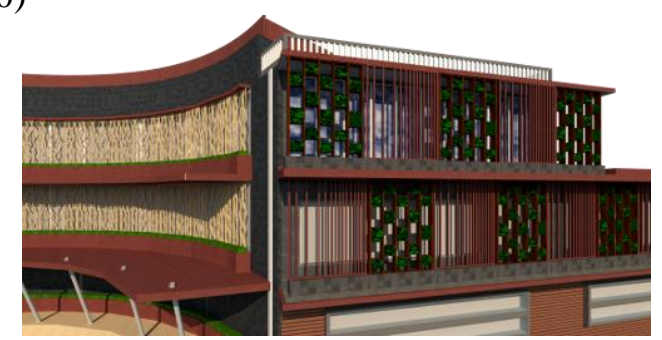

Gambar 10. Sun Shading dan Teritisan pada Eksterior Bangunan 


\section{b. Landscape: Pedestrian}

Salah satu aspek ekologi ialah dengan memfasilitasi area pedestrian dengan melakukan penataan vegetasi peneduh agar tercipta lingkungan yang aman dan nyaman bagi pejalan kaki. (lihat Gambar 11)

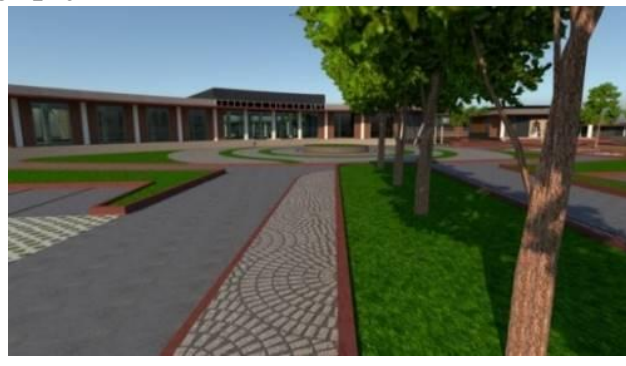

Gambar 11. Pedestrian dalam Site

\section{c. Landscape: Plaza}

Adanya plaza dan pengolahan pada hardscape bangunan menambah nilai estetika dan kenyamanan, sehingga pengguna bangunan dapat berjalan dengan nyaman di dalam site. (lihat Gambar 12)

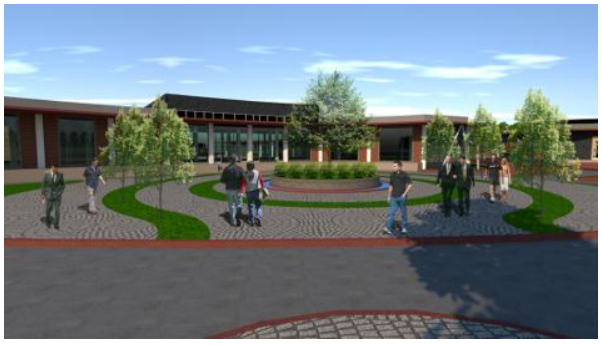

Gambar 12. Plaza dalam Site

Pengadaan elemen air dalam site sebagai salah satu bentuk pengatur iklim pada landscape bangunan. (lihat Gambar 13)

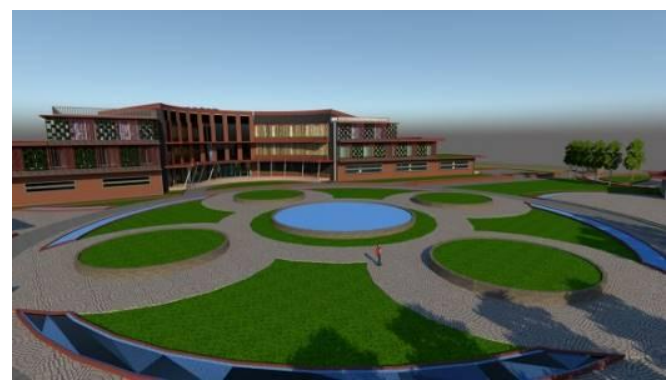

Gambar 13. Elemen Air dalam Site

\subsection{Bentuk dan Gubahan Massa}

Penentuan bentuk dan gubahan masa menerapan bentuk yang menunjukkan bentuk alam yaitu bentuk melingkar dan melengkung, bersifat dinamis dan tidak terkesan kaku, sebagai salah satu penerapan teori arsitektur ekologi, yaitu bentuk massa yang menyesuaikan bentuk site dan pola sirkulasi dalam site. (lihat Gambar 14)

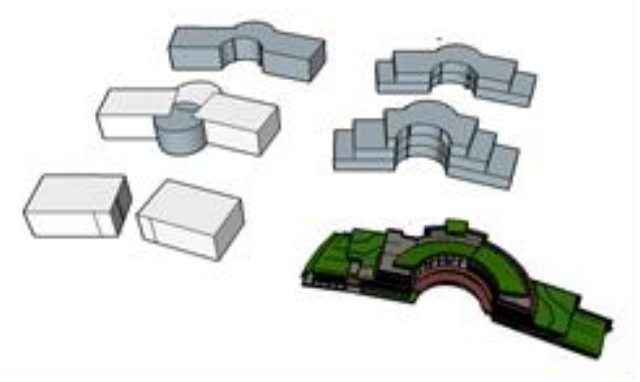

Gambar 14. Gubahan Massa Utama

Pola tata massa merupakan pola massa terpusat dengan massa jamak (lihat Gambar 15) yang terbagi berdasarkan kelompok kegiatan dan fungsinya, mencerminkan pola tatanan yang terikat pada suatu pusat yaitu massa kegiatan utama, serta aplikasi ruang luar dan sirkulasi yang fleksibel dan dinamis menyesuaikan dengan pendekatan Arsitektur Ekologi yaitu desain yang beradaptasi dengan lingkungan. Selain itu, perancangan sirkulasi yang berbentuk lengkung dan melingkar serta saling berhubungan.

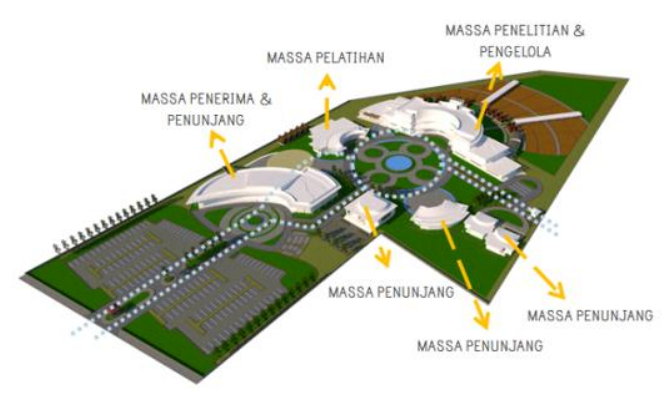

Gambar 15. Pola Tata Massa Terpusat

\subsection{Material dan Bahan}

Material yang digunakan ialah material yang ramah lingkungan yang siklus pengadaannya tidak mengganggu keseimbangan alam serta sebisa mungkin menerapkan sistem reuse, reduce dan recycle. 


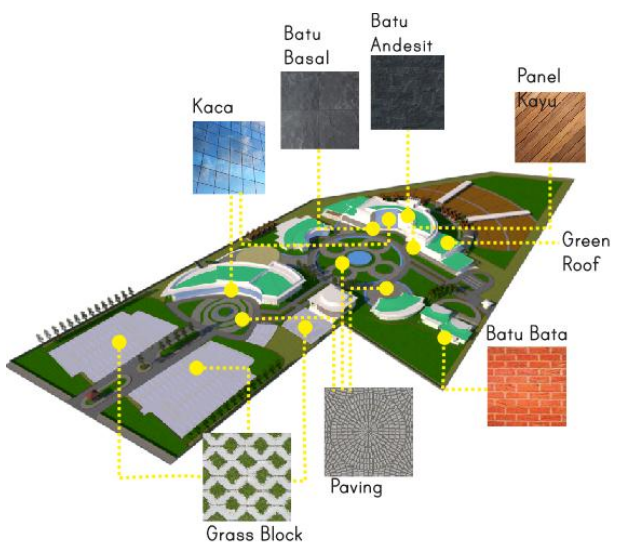

Gambar 16. Material Bangunan

Elemen vegetasi merupakan salah satu elemen penting dalam menciptakan kenyamanan, suasana dan penghawaan pada bangunan. Elemen vegetasi yang digunakan tidak hanya berfungsi sebagai nilai estetika namun juga memiliki fungsinya sendiri.

Vegetasi yang akan digunakan ialah Pohon Akasia dan Angsana sebagai vegetasi peneduh, pohon palem dan cemara Norfolk sebagai vegetasi pengarah, pohon jati putih, semak dan perdu serta berbagai jenis bunga sebagai vegetasi penyejuk dan rumput jepang dan mirton sebagai vegetasi ground cover. (lihat Gambar 17)

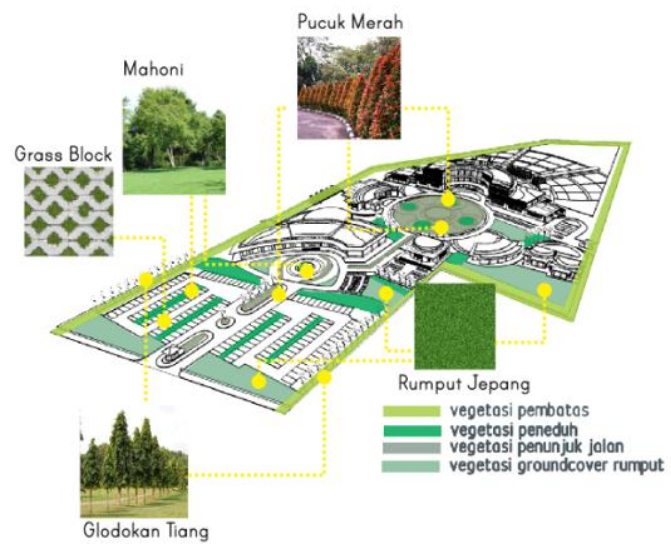

Gambar 17. Vegetasi pada Site

Vegetasi yang cocok ditanam pada roof garden ialah tanaman yang tidak memiliki pertumbuhan akar ke bawah, tahan terhadap paparan sinar matahari, dan tidak memiliki perawatan yang rumit. Contohnya aracea, lili paris, dan rulea, bougainville, jeruk, melati, kembang sepatu. (lihat Gambar 18)

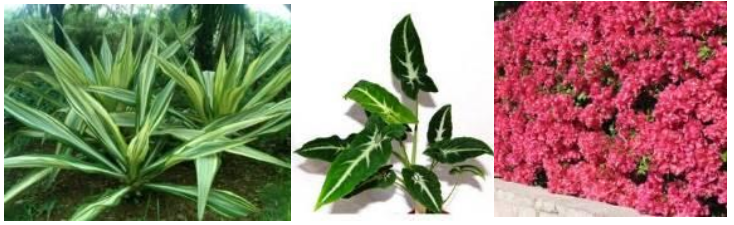

Gambar 18. Vegetasi pada Roof Garden (greenhomesindonesia.com, 2017)

\subsection{Utilitas Bangunan}

Atap bangunan menggunakan struktur atap greenroof, yaitu struktur atap yang menggunakan tanah dan vegetasi sebagai penangkap air hujan (lihat Gambar 19), sehingga air tidak mengalir langsung ke pembuangan. Adanya greenroof dapat meningkatkan kualitas lingkungan, karena air yang jatuh melalui filtrasi pada tanah dan tanaman yang berada di atas atap sebelum nantinya dimanfaatkan sesuai kebutuhan.

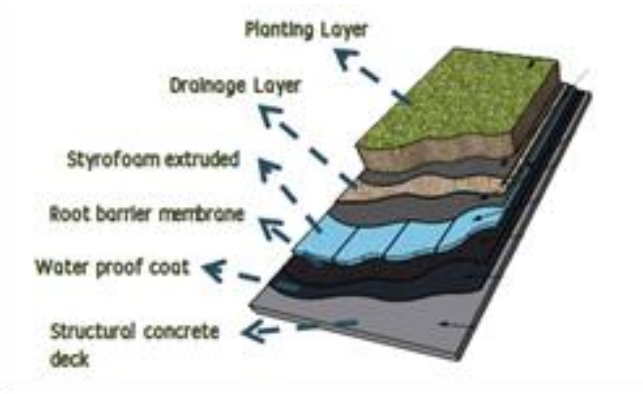

Gambar 19. Struktur Greenroof (sempergreen.com, 2017)

Air hujan yang jatuh pada daerah resapan berupa grassblock dan tanah langsung diresap ke dalam tanah, sedangkan air hujan yang jatuh pada atap dialirkan dan ditampung untuk kemudian digunakan kembali sebagai air flush toilet, air sprinkler serta untuk mengairi kolam dalam site.

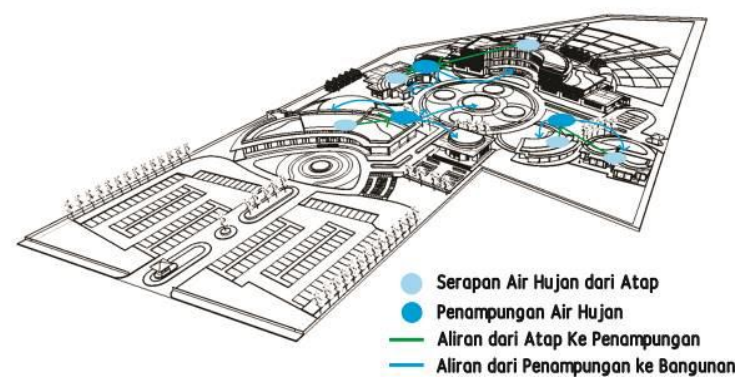

Gambar 20. Skema Air Hujan dalam Site 


\section{Hasil Rancangan}

Pusat Penelitian Agrikultur yang dirancang akan dapat mewadahi kegiatan penelitian dengan mengadakan fasilitas penelitian berupa laboratorium dan ruang penunjang lainnya di Kabupaten Sragen. Penerapan strategi desain Arsitektur Ekologi menggunakan 3 poin utama intisari dari teori Arsitektur Ekologi sebagai pemecahan masalah atas persoalan desain yang muncul pada objek rancang bangun, sehingga nantinya diharapkan hasil rancangan dapat mewadahi kegiatan di dalamnya secara holistis. Dengan tercapainya tujuan perancangan objek rancang bangun, diharapkan dapat mewadahi kegiatn penelitian dengan baik sehingga dapat memajukan pertanian Indonesia kelak di masa mendatang.

Perancangan desain Pusat Penelitian Agrikultur dengan Strategi Perancangan Arsitektur Ekologi sebagai berikut:

Nama Bangunan: Pusat Penelitian

Lokasi: Jl. Raya Maospati - Solo, Kecamatan Masaran, Kabupaten Sragen

Luas Lahan: $43.941 \mathrm{~m} 2$

Luas Bangunan: 9.169,68 m2

Kegiatan: Penelitian, Pelatihan, dan

Penunjang

\section{KESIMPULAN}

Penerapan konsep Arsitektur Ekologi sebagai suatu strategi perancangan Pusat Penelitian Agrikultur merupakan suatu langkah yang tepat demi mencapai perancangan objek rancang bangun yang dapat mewadahi kegiatan yang berkaitan dengan alam secara holistis. Teori Arsitektur Ekologi menekankan terhadap hubungan elemen-elemen yang saling terkait di dalamnya, yaitu manusia, bangunan dan juga alam sekitarnya.

Hal ini diaplikasikan dengan 3 poin utama teori Arsitektur Ekologi yaitu desain yang beradaptasi dengan lingkungan, memanfaatkan sumber daya alam dan energi serta keseimbangan antara sistem bangunan dengan alam sekitar.

\section{REFERENSI}

Bonan, Gordon. (2002). Ecological Climatology Concept \& Applications. Cambridge: Cambridge University Press.

Frick, Heinz. (1998). Dasar-Dasar EkoArsitektur. Yogyakarta: Kanisius.

Frick, Heinz \& Tri Hesti Mulyani. (2006). Arsitektur Ekologis, Konsep Arsitektur Ekologis di Iklim Tropis, Penghijauan Kota dan Kota Ekologis di Iklim Tropis serta Energi Terbarukan. Yogyakarta: Kanisius.

Lechner, Norbert. (2001). Heating, Cooling, Lighting: Design Methods for Architects. New York: John Wiley \& Sons Inc.

Mc. Harg, Ian L. (1967). Design with Nature. New York: John Wiley \& Sons Inc.

Odum, Euguene. (1971). Fundamentals of Ecology $3 r d$. Philadelphia: W.B Saunders Company.

Williams, Daniel E. (2007). Sustainable Design: Ecology Architecture \& Planning. New Jersey: John Wiley \& Sons Inc. 